\title{
機能を見る組織化学一蛍光イメージングによる 心臓機能分子の動態解析一
}

田中 秀央

要約 : 蛍光イメージング法は, 組織・細胞内の特定の 構成成分や機能分子を蛍光画像化する組織化学の基本 的手法である。近年の顕微イメージング技術と蛍光プ ローブの目覚ましい進歩により, 細胞内の蛍光機能分 子が高い時間空間分解能で可視化できるようになり, 生きた組織・細胞の機能解析が可能になった。ここで は, 筆者が取り組んできた心筋組織の蛍光機能イメー ジングから得た以下の成果を紹介し, 機能を見る組織

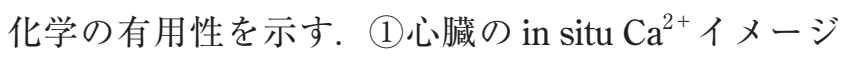
ング : ラットの摘出灌流心に高速共焦点顕微鏡を適用 し, 心筋細胞の $\mathrm{Ca}^{2+}$ 動態を高い時間空間分解能で可視 化した。 心臓が $\mathrm{Ca}^{2+}$ 過負荷に陥ると拡張期に筋小胞 体から $\mathrm{Ca}^{2+}$ が自発性に放出されて個々の心筋で $\mathrm{Ca}^{2+}$ 波が発生し，これが心臓内で同時多発すると不整脈原 性の異常興奮が生じる。一方, 筋小胞体からの $\mathrm{Ca}^{2+}$ 放 出が損なわれると収縮期に細胞内・細胞間で $\mathrm{Ca}^{2+}$ 放 出が空間的に不均一になり, 一拍毎に $\mathrm{Ca}^{2+}$ 濃度が交代 性に増減する $\mathrm{Ca}^{2+}$ オルタナンスが生じる。この不均 一な $\mathrm{Ca}^{2+}$ 動態は小動物の心房や不全心で観察される 横行小管 (T管) の発現低下が一因とされ, 心藏の収 縮・拡張機能を反映する上で重要な現象と考えられる. (2)ギャップ結合機能異常による不整脈 : 心筋細胞間の 電気的結合を担う $\mathrm{Cx} 43$ の機能をラット新生仔心筋の 単層培養組織でドミナントネガティブ阻害すると, 心 筋組織の伝導速度が低下し, 旋回性に興奮伝導する不 整脈が起こりやすくなることを見出した. (3)心房細動 の組織形態学的発生基盤：ラット摘出灌流心に心房細 動を誘発し膜電位感受性蛍光プローブのイメージング 下によりその発生起源を同定, 組織学的解析との統合 により心房に内在する不整脈原性基質を明らかにした。 以上, 生きた心臓組織の蛍光機能イメージングは, 心 臓の興奮伝導やその異常の解明に有用な情報をもたら してくれる.

\section{1.はじめに}

組織化学は組織・細胞の化学反応を利用して特定の 物質・分子の空間的分布を同定する，生命科学におけ る有用な研究手法である。通常の組織化学では固定し た生物試料から薄切切片を作成し, 組織・細胞内の特 定の物質・分子を色素で染め分けてこれらの分布像や 組織形態像を得る。しかし, 固定された試料ではその 機能や機能分子の動態を知ることはできない，生きた 臓器・組織を時間軸の上に立って機能分子の動態を捉 える「機能を見る組織化学」が必要になる。なかでも 心臟不整脈の研究では, 組織形態や分子の分布のみか らその発生機序を解明することは困難であり, 高い時 間分解能で興奮伝導様式を可視化することが必要であ る.ここでは心筋細胞のカルシウムイオン $\left(\mathrm{Ca}^{2+}\right)$ 動 態や膜電位変化の高速蛍光イメージングから心臓の機 能を捉え, その背景にある組織形態や機能分子の異常 から明らかとなった筆者らの研究成果を提示し, 機能 を見る組織化学の意義を考えたい。

\section{2. 高速共焦点レーザー顕微鏡}

蛍光顕微鏡法は光吸収した分子から発せられる蛍光 を利用して組織や細胞内の分子の空間的分布を可視化 する光学的手法である. しかし, 試料を一様に照射す る通常の全視野型蛍光顕微鏡では, 光が一点から発せ られてもレンズを通ると空間的に拡がってしまうため, 厚みのある組織の蛍光観察では光が拡がって標本内で 散乱しボケた像しか得られない。この問題を解決した のが共焦点レーザー顕微鏡（以下，共焦点顕微鏡）で ある. 小さなレーザー光スポットで試料を励起し, 光 検出器の前の共焦点位置にピンホールを置くことによ り, 焦点面上のスポットから出た蛍光だけが光検出器 に届き，焦点外からの迷光はピンホールで遮られる

キーワード：蛍光イメージング，高速共焦点レーザー顕微鏡，カルシウム，不整脈，コネキシン 43 京都府立医科大学大学院 医学研究科 細胞分子機能病理学（ E-mail: hideotan@koto.kpu-m.ac.jp＼cjkstart原稿受領日：2019 年 7 月 2 日，依頼原稿 


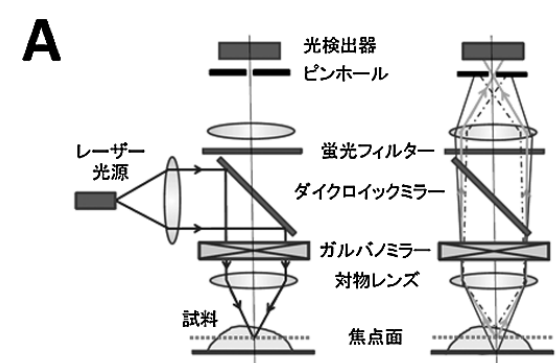

B

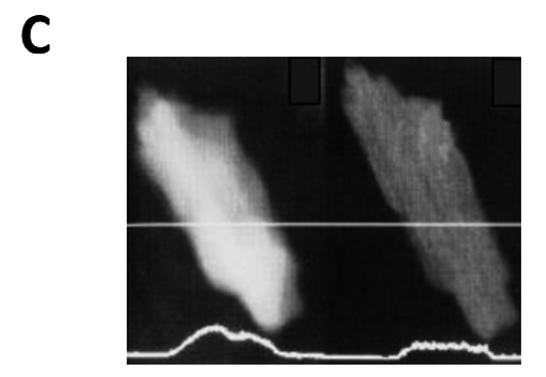

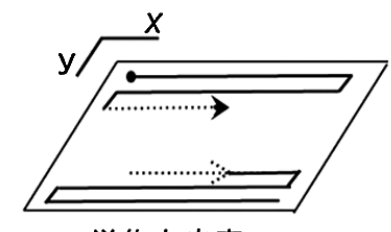

単焦点走査

D

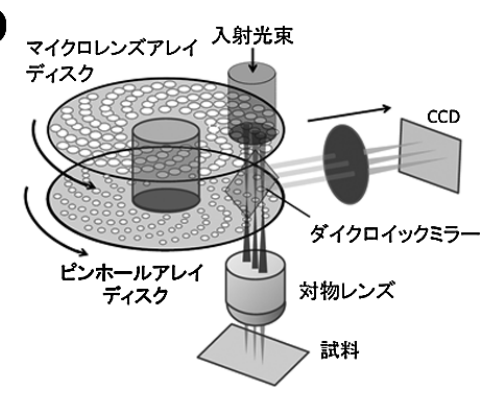

\section{図 1 共焦点顕微鏡の原理}

(A) 共焦点顕微鏡の光路の模式図. (B) 単一点共焦点走査の模式図. (C) ラット単離心筋細胞の Fluo3 蛍光画像の比較. 非共焦点の蛍光像 （左）では Fluo3 の蛍光強度が細胞の厚みに影響されるが共焦点像（右）では厚みの影響はない．（D）多点高速共焦点走査装置の概略図。（A，

B, D は組織細胞化学 2014 pp. 127-134（2014）（日本組織細胞化学会）より，C は文献2より転載）

(図 1A). 焦点面のピンホールを絞ってXY平面上を点 走查（図 1B）すれば，分解能の高い蛍光画像を得るこ とができる(1)。また，共焦点顕微鏡で得られた画像 の蛍光強度変化は一定の厚さの試料からの蛍光物質の 濃度を反映するため, 細胞機能の解析にも有用である (図 1C) (2).

基本的な共焦点顕微鏡ではガルバノメーターミラー により XY 平面を点走査することによって画像を得る。 ところがこの走査方式では 1 枚の共焦点像を得るのに 秒単位の時間がかかるため, 画像内で取得される蛍光 情報に時間差が生じてしまう。生きた組織・細胞を共 焦点解析するにはミリ秒単位の高い時間分解能で視野 全体の蛍光強度変化を同時に捉える必要がある。これ を可能にしたのが多点走査システムである（図 1D）. これは多数のピンホールが配置された円盤（Nipkow disc）を高速回転させることによって試料を高速で多 点照射するもので, 各ピンホールに対応させてマイク ロレンズを付けることで蛍光強度の高い高速画像（最 高 1000 コマ/秒）が得られる. 我々は多点走査によ る高速共焦点顕微鏡を用いて機能している心臓の蛍光 強度変化を高時間分解能で可視化し, 心筋細胞の $\mathrm{Ca}^{2+}$ 動態を細胞下レベルで解析している(3).

\section{3. 心蔵の in situ $\mathrm{Ca}^{2+}$ イメージング}

心臟は個々の心筋細胞が互いに調和して興奮・収縮 することによってポンプ機能を発揮する機能的合胞体 である。 その機能の要となる細胞内シグナルが $\mathrm{Ca}^{2+}$
であり, 心筋の電気的興奮を筋収縮に変換する興奮収 縮連関（E-C coupling）の仲立ちとして働いている. 図 2Aに示すように, 心筋が電気的に興奮すると L 型 $\mathrm{Ca}^{2+}$ チャネル（L-Ca）の活性化により細胞内に少量の $\mathrm{Ca}^{2+}$ が流入し，これが引き金となって直下の筋小胞体 (sarcoplasmic reticulum : SR) 上の ryanodine 受容体 (ryanodine receptors : RyR) から大量の $\mathrm{Ca}^{2+}$ が放出さ れ $\left(\mathrm{Ca}^{2+}\right.$ 誘導性 $\mathrm{Ca}^{2+}$ 放出), 一過性に $\mathrm{Ca}^{2+}$ 濃度が上昇 する $\left(\mathrm{Ca}^{2+}\right.$ トランジェント)。濃度上昇した $\mathrm{Ca}^{2+}$ は troponin $\mathrm{C}$ と結合し筋収縮した後, 主に $\mathrm{Ca}^{2+}$-ATPase （SERCA）を介する SRへの再取り込みと細胞膜上の $\mathrm{Na}^{+}-\mathrm{Ca}^{2+}$ 交換体 (NCX) を介する細胞外への排出に よって低濃度の状態に戻り, 心筋を弛緩させる (4). 図 2B は $\mathrm{Ca}^{2+}$ 蛍光指示薬の Fluo4 を負荷したラット摘 出灌流心表面の高速共焦点顕微鏡像である. 健常な 心臟では心拍に伴って個々の心筋で時間的 - 空間的に 均一な $\mathrm{Ca}^{2+}$ トランジェントが生じるが, 拡張期には $\mathrm{Ca}^{2+}$ は低濃度に保たれる(5)。一方, $\mathrm{Ca}^{2+}$ 過負荷に 陥った心筋では拡張期に細胞内の局所で $\mathrm{Ca}^{2+}$ 濃度が 自発性に上昇し, これが細胞内を伝播して $\mathrm{Ca}^{2+}$ 波 $\left(\mathrm{Ca}^{2+}\right.$ wave) とよばれる異常な $\mathrm{Ca}^{2+}$ 動態が生じる (5). $\mathrm{Ca}^{2+}$ 波は細胞内 $\mathrm{Ca}^{2+}$ 負荷の増強とともに発生しやす くなり，その伝播速度も速くなる（図 2C). とくに高 頻度駆動下や頻拍時には拡張期に多数の細胞が高頻度 の $\mathrm{Ca}^{2+}$ 波が生じ, これが一定の領域で同時多発すると しばしば $\mathrm{Ca}^{2+}$ トランジェントが惹起される（図 2D) (6). 

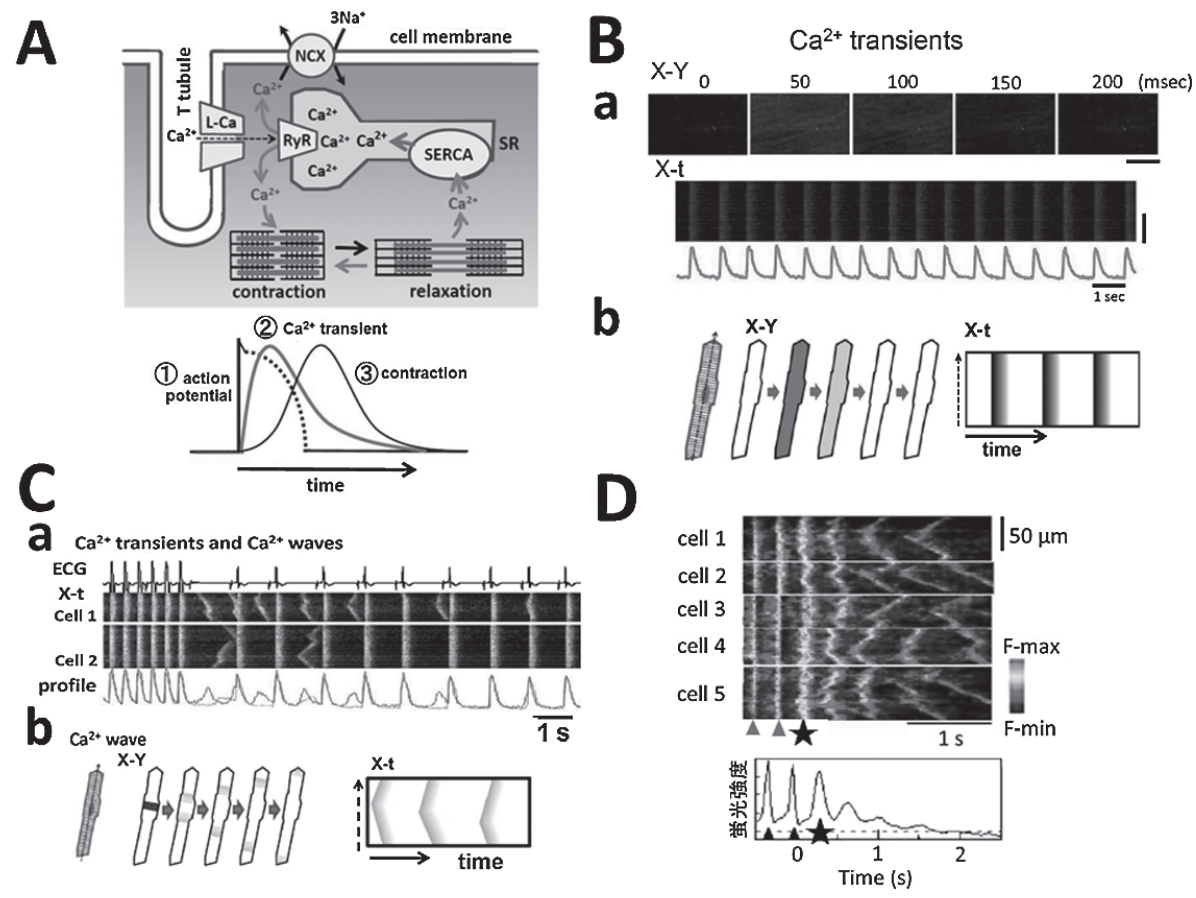

図 2 心筋細胞の $\mathrm{Ca}^{2+}$ 動態

(A) 心筋の興奮・収縮連関における $\mathrm{Ca}^{2+}$ の役割（模式図）。略語は本文参照.（B-a）ラット摘出灌流心の Fluo4 共焦点蛍光画像. X-Y 画像 (上 段) とX-t 画像とプロファイル波形 (中段). (B-b) 単一心筋細胞 (X-Y) の $\mathrm{Ca}^{2+}$ トランジェントから得た X-t 画像取得の模式図 (下段)。(C-a)

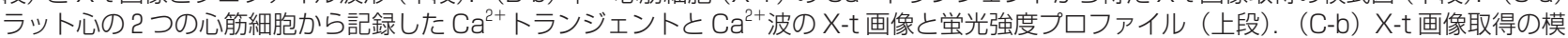

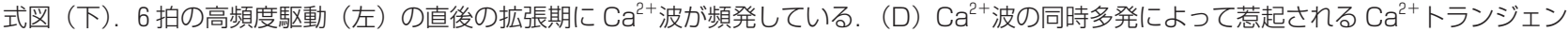
$卜(\star)$. 二拍の電気刺激 $(\boldsymbol{\Delta})$ 後に発生. 心筋細胞 (1-6) の X-t 画像 (上) と 6 細胞の平均蛍光強度変化 (下). ( A, B, C は文献 11 より, D は文献 6 より転載）
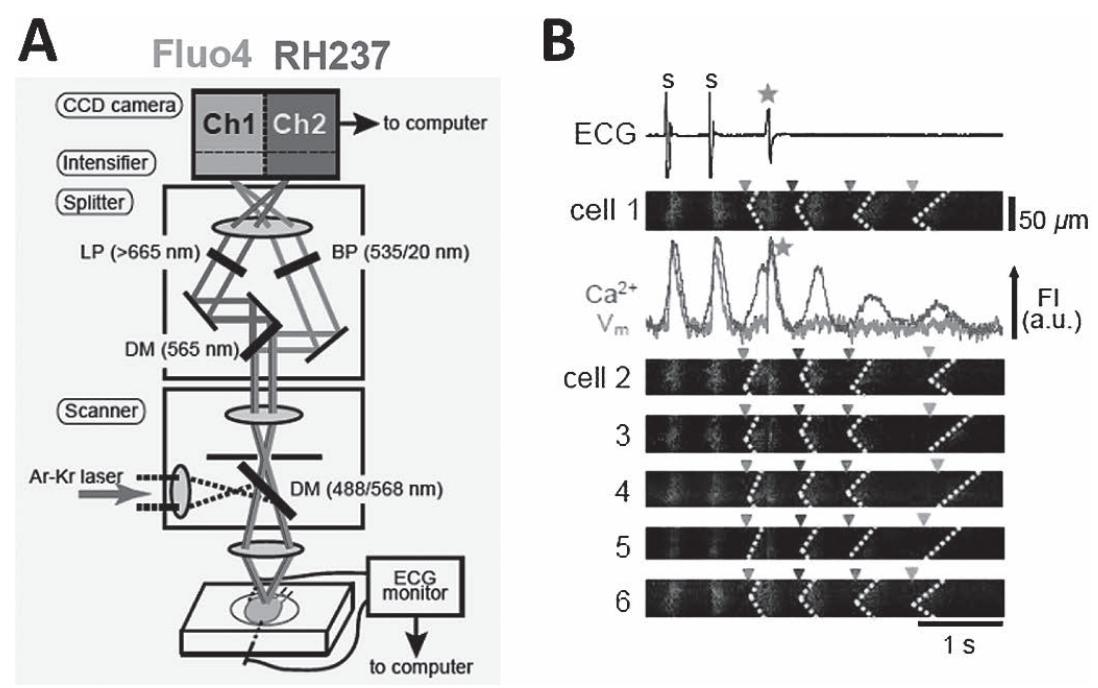

図 32 波長高速共焦点顕微鏡による心筋細胞内 $\mathrm{Ca}^{2+}$ と細胞膜電位変化の同時蛍光取得 （A）光路図.（B） $\mathrm{Ca}^{2+}$ 波の同時多発によって惹起される撃発活動（ネ).（文献7より転載）

\section{4. 心筋の $\mathrm{Ca}^{2+}$ 動態と膜電位変化との同時可視化}

$\mathrm{Ca}^{2+}$ 波の同時多発に伴って生じる $\mathrm{Ca}^{2+}$ トランジェ ントが電気的興奮を惹起するのか否かは不明であった。 そこで心臓にFluo4 と膜電位感受性蛍光プローブ RH237 とを負荷し，心表面の心筋細胞の $\mathrm{Ca}^{2+}$ 動態と 膜電位変化との同時蛍光観察を試みた (7). 高速共焦
点顕微鏡に蛍光分離ユニットを増設し, 蛍光を $\mathrm{Ca}^{2+}$ 濃 度変化（505～555 nm） と膜電位変化（>650 nm）の 2 つの波長成分に分離して CCD カメラ (270 コマ/秒) で取得した（図 $3 \mathrm{~A}$ )。その結果, $\mathrm{Ca}^{2+}$ 波の同時多発が 電気的に異常な興奮（撃発活動：triggered activity）を 惹起することがわかった (図 3B)。 また,この異常興 奮は NCX 阻害薬の SEA0400 により消失したことから, 
細胞内 $\mathrm{Ca}^{2+}$ の濃度上昇が $\mathrm{NCX}$ をして $\mathrm{Na}^{+}$の細胞内 流入 $\left(\mathrm{Ca}^{2+}\right.$ と $\mathrm{Na}^{+}$の交換比 $\left.1: 3\right)$ をもたらして心筋を 脱分極・発火させることも明らかになった (7).ささらに, この撃発活動に続く興奮の連発 (心室頻拍) P $\mathrm{Ca}^{2+}$ 濃 度の増減に伴う振動性の脱分極 (delayed after depolarizations：DADs）も確認された(7)。このような細胞内 $\mathrm{Ca}^{2+}$ 濃度の自発性の上昇によって惹起される撃発性 不整脈は心不全 $(8,9)$ や RyR 遺伝子の異常 (10) で生 じやすいことが知られている.

\section{5. 収縮期の $\mathrm{Ca}^{2+}$ 波と $\mathrm{Ca}^{2+}$ オルタナンス}

心臓の拡張期に生じる上記の $\mathrm{Ca}^{2+}$ 波とは異なり, 収 縮期にも $\mathrm{Ca}^{2+}$ 波様の異常な $\mathrm{Ca}^{2+}$ 動態が観察される. これは虚血や代謝阻害によってもたらされる RyRの $\mathrm{Ca}^{2+}$ 放出障害と SERCAによる $\mathrm{Ca}^{2+}$ の再取り込み障害 に起因する（図 4A) (11)。このような状態では細胞内・ 細胞間で $\mathrm{Ca}^{2+}$ 動態が時間空間的に不均一になり, 興奮 頻度が高まるにつれて不均一性がより顕著になってし ばしば $\mathrm{Ca}^{2+}$ トランジェントの振幅が一拍毎に交代性 増減する (図 $4 \mathrm{~B})$ 。この現象は $\mathrm{Ca}^{2+}$ オルタナンス $\left(\mathrm{Ca}^{2+}\right.$ alternans）と呼ばれ，興奮時に SR から十分量の $\mathrm{Ca}^{2+}$ が 放出されると均一な $\mathrm{Ca}^{2+}$ トランジェントが発生する が，次の興奮では $\mathrm{Ca}^{2+}$ 放出が不十分となって $\mathrm{Ca}^{2+}$ 波 様の異常動態を示し, さらに次の心拍では SR からの $\mathrm{Ca}^{2+}$ の放出量が回復し均一な $\mathrm{Ca}^{2+}$ トランジェントに なる, といった一連の $\mathrm{Ca}^{2+}$ 放出量の増減が繰り返され
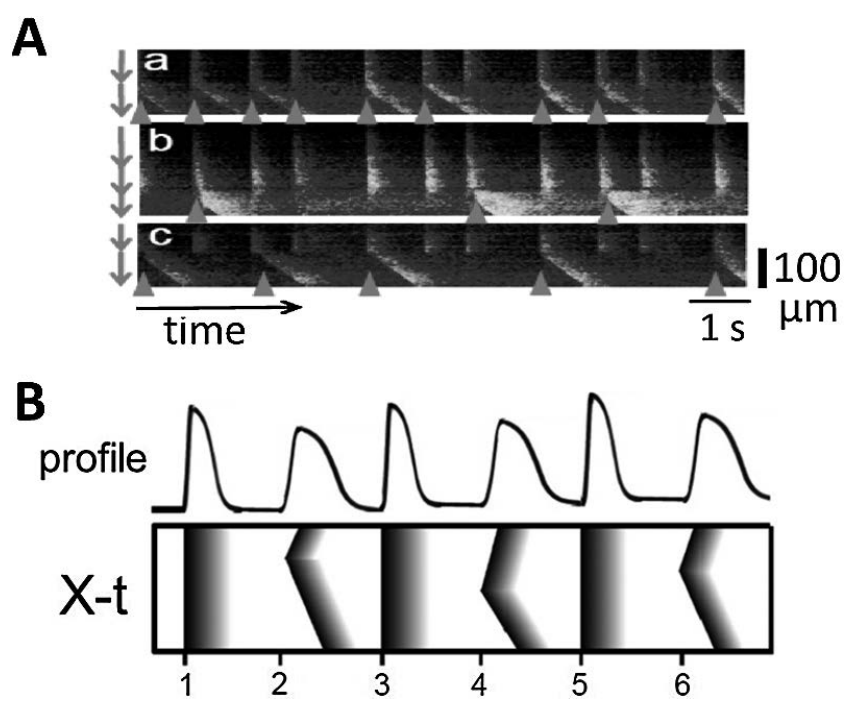

図 4 収縮期の $\mathrm{Ca}^{2+}$ 波

(A) 収縮期に発生する心室筋の $\mathrm{Ca}^{2+}$ 波 (上段) のX-t 像．左矢印は個々 の心筋細胞を示す. 細胞 $\mathrm{a}, \mathrm{b}, \mathrm{c}$ の $\mathrm{Ca}^{2+}$ トランジェントに伴って隣接 する細胞が収縮期に $\mathrm{Ca}^{2+}$ 波を示している(矢頭)。(B) $\mathrm{Ca}^{2+}$ オルタナ ンスの X-t 像の模式図 (下段). 奇数番目の心拍で均一な $\mathrm{Ca}^{2+}$ トラン ジェントが生じ, 偶数番目の心拍で $\mathrm{Ca}^{2+}$ 波が生じている.（文献 $11 よ$ り転載)

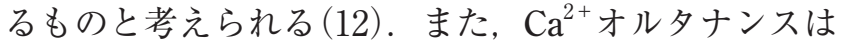
活動電位持続時間や収縮張力の交代性の増減とも関連 している(13).このような細胞内・細胞間で生じる不 均一な $\mathrm{Ca}^{2+}$ 動態は収縮能の低下につながるものと示 唆される. 実際, $\mathrm{Ca}^{2+}$ オルタナンスは不全心で発生 することが知られており (14), 心電図 T 波や収縮張力 のオルタナンスから致死性不整脈発生の予知も可能と もされている(15)。しかし, $\mathrm{Ca}^{2+}$ オルタナンスの不整 脈原性機序については十分には明らかになっていない.

\section{6. 横行小管（ $\mathrm{T}$ 管）と心筋 $\mathrm{Ca}^{2+}$ 動態}

細胞媣部への細胞膜の嵌入構造である横行小管 (transverse tubule：T管）は, 細胞全体に均一な $\mathrm{Ca}^{2+}$ トランジェントをもたらして効率良い興奮収縮連関を 可能にする．ところが心室筋に比べて特にマウスや ラットなど小動物の心房筋では T 管の発現がそしく, $\mathrm{Ca}^{2+}$ 誘導性 $\mathrm{Ca}^{2+}$ 放出の効率が心室筋に比べて悪い (図 5A)。このためこれら心房の $\mathrm{Ca}^{2+}$ 動態は時空的に不 均一化しやすくなり, とくに高頻度の興奮時で不均一 性が顕著になる $(16,17)$. 興味深いことに, 個々の細胞 で観察される不均一な $\mathrm{Ca}$ 動態は心筋組織レベルでの 濃度変化としてみると $\mathrm{Ca}^{2+}$ オルタナンスとなる (図 $5 \mathrm{~B}$ ). T管の発現低下は不全心においても観察され（T管リ モデリング), 心臟の収縮能低下を示唆する重要な形 態的異常と考えられている(18)，実際にT管リモデリ ングに伴って不全心では $\mathrm{L}$ 型 $\mathrm{Ca}^{2+}$ チャネルと機能的 にカップリングしていない RyR (“orphaned RyRs”) が 増え (19), 結果的に不均一な $\mathrm{Ca}^{2+}$ transients を示す (20). 不均一な $\mathrm{Ca}^{2+}$ 動態の病態, とくに不整脈原性について は膜電位変化と $\mathrm{Ca}^{2+}$ との同時蛍光記録等によるさら なる解明が必要である。

\section{7. ギャップ結合機能阻害による不整脈の蛍光 イメージング}

心臓は個々の心筋細胞がギャップ結合を介して電気 的に結合することによって合胞体としての機能を担っ ている，心室筋の介在板に存在する主要なギャップ結 合タンパク質であるコネキシン 43 （Cx43）は梗塞心, 不全心，肥大心などの病的心でその発現が減少したり， 分布が変化したりすること（ギャップ結合リモデリン グ）が知られ，こうした変化が心臓の伝導障害をもた らして不整脈を発生させる可能性がある(21)。しかし ながら, 生体で Cx43 の分布と心筋の興奮・伝播とを 同時に観察することが困難であったため, Cx43の発 現異常と不整脈の発生との関連については不明であっ た。そこで我々は新生仔ラット培養心筋細胞の単層組 

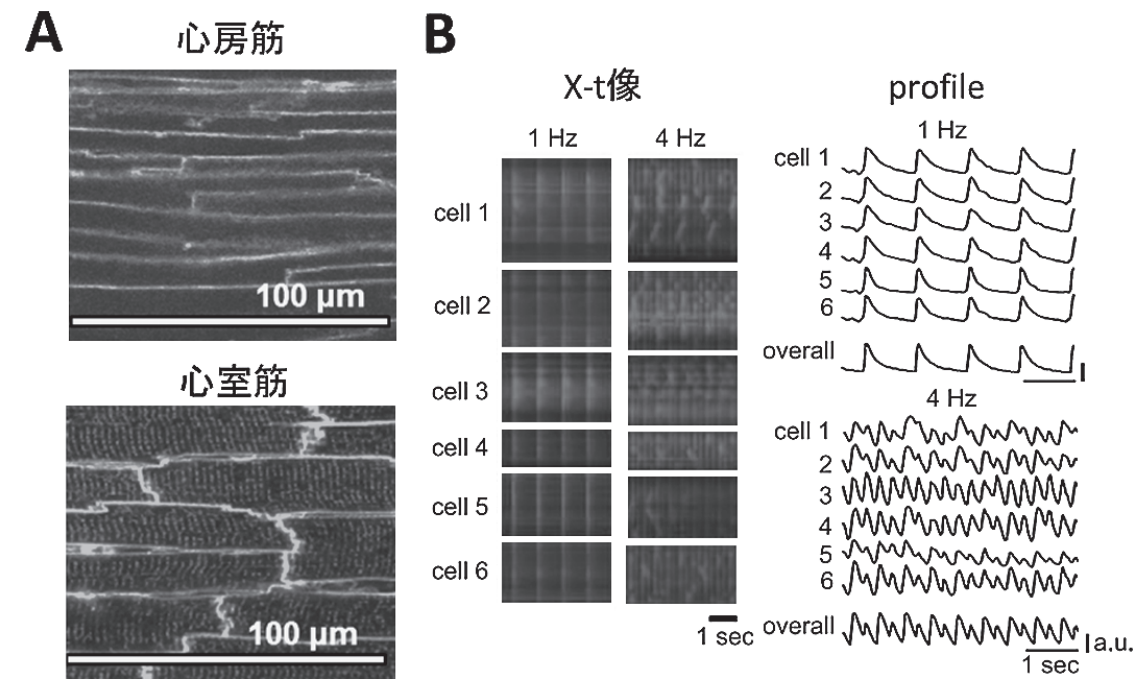

図 5 ラット心房筋の $\mathrm{Ca}^{2+}{ }^{+}$動態異常

(A) ラットの心房筋と心室筋との組織形態の比較. di-4-ANEPPS 蛍光の共焦点画像. 心室筋は密な丁管を有するが心房筋には丁管を殆じ認め ない. (文献7より転載) (B) ラット心房筋の不均一な $\mathrm{Ca}^{2+}$ 動態. $1 \mathrm{~Hz}$ の興奮では均一な $\mathrm{Ca}^{2+}$ トランジェントが生じるが $4 \mathrm{~Hz}$ の興奮では $\mathrm{Ca}^{2+}$ 動態が不均一になる. 細胞 1〜6の Fluo4 共焦点蛍光 X-t 像（左）とその蛍光強度のプロファイル（右）. $4 \mathrm{~Hz}$ では個々の細胞が不均一な Ca ${ }^{2+}$ 動態を示すが, 平均すると $\mathrm{Ca}^{2+}$ オルタナンスを呈している.（文献 16 より転載）

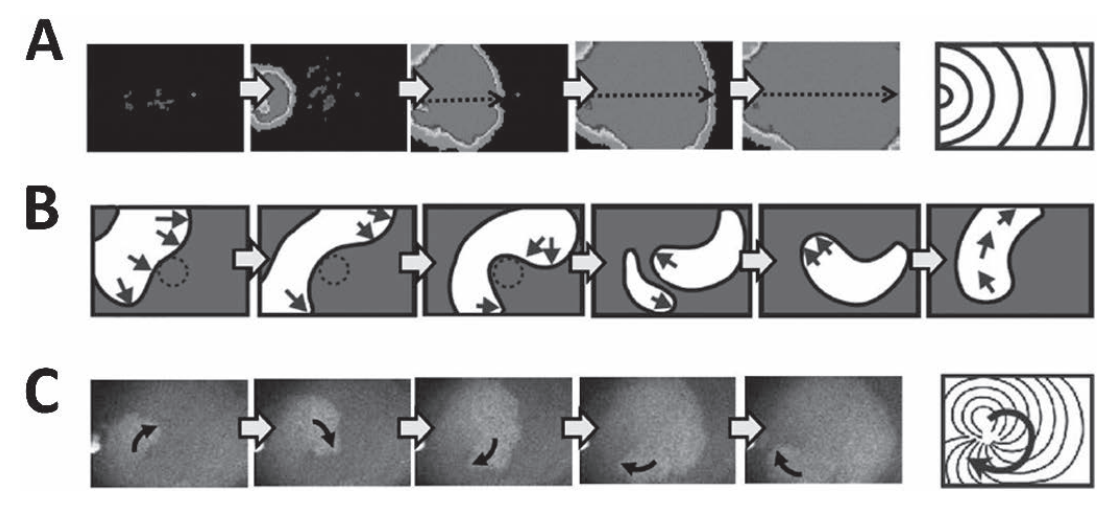

図 6 単層培養心筋組織の興奮伝導（新生仔ラット）

(A) 新生仔ラット心筋の単層培養組織の Fluo4 興奮伝導様式. 左から右へ興奮波が伝導している. (B) Cx43のドミナントネガティブ阻害によ り生じた旋回性の伝導の模式図。（C）は旋回性伝導の Fluo4 蛍光像の実例. A と C の右端には伝導の等時曲線を示す。（文献 11 より転載）

織を用いて Cx43 の機能をドミナントネガティブ阻害し, 実体蛍光顕微鏡を用いて $\mathrm{Ca}^{2+}$ 動態による興奮伝播を 高感度超高速 CCD カメラ (毎秒 455 コマ) で可視化し た(22)。さらにドミナントネガティブCx43 (DN-Cx43) には赤色蛍光タンパク質 $\mathrm{mRFP}$ を付加した。 その結 果, $\mathrm{Cx} 43$ のドミナントネガティブ阻害が心筋組織の 伝導を抑制し, 旋回性の不整脈（スパイラルリエント リー）を惹起しやすくなることが分かった(22)。また, 不整脈の発生に至る興奮伝導過程を詳細に観察したと ころ, 発生に先立って興奮波の先端の均一性が崩れ, 刺激興奮頻度の上昇に伴ってその不均一性が増大し, これに引き続く局所的な興奮波の途絶が旋回性興奮を もたらすことも明らかになった（図 6).ささらに, 旋回 性不整脈の発生起点となる興奮途絶領域に一致して $\mathrm{DN}-\mathrm{Cx} 43$ 遺伝子の発現（mRFP 蛍光）が周囲の領域よ
りも強いことを見出した.これらの結果は $\mathrm{Cx} 43$ 機能 の低下，とくに空間的に不均一な機能低下が旋回性不 整脈の発生基質になることを示唆するものである. 不 全心で認められる不均一な Cx43 の分布（リモデリン グ）が不整脈の原因として重要な役割を演じている可 能性がある。

\section{8. 心房細動の蛍光機能イメージング一心房細 動の組織形態学的発生基盤—}

線維化など心臓の組織形態異常が不整脈の発生に深 く関わっていることは広く知られている $(23)$ が, 健常 な心臟においても不整脈の発生に関わる内在性の形態 異常がある. とくに心房には肺静脈と左心房との境界 部に細動発生の起源があることが知られ，心房細動の 抑止に同部の焼灼が有効である (24)。健常心に内在す 


\section{A}
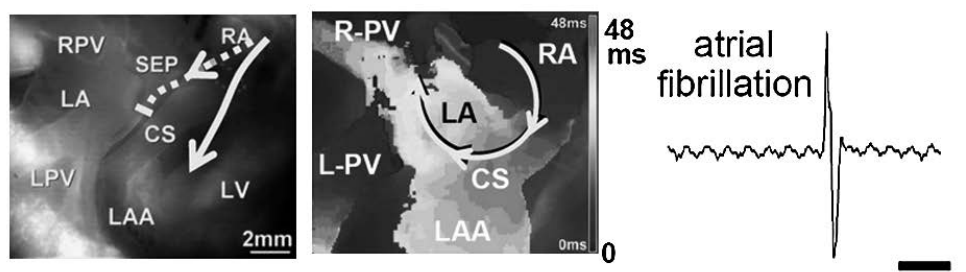

B
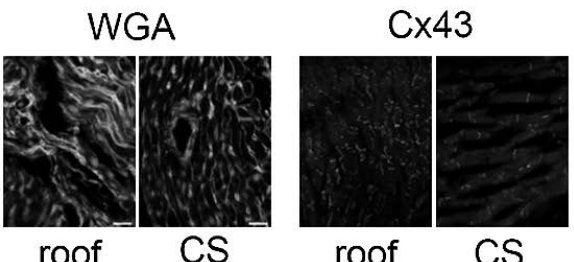

Masson

$100 \mathrm{~ms}$

roof

CS

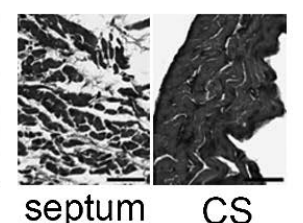

図 7 ラット心の心房細動と心房組織

(A) ラット摘出心に誘発された心房細動. 左心房の di-4-ANEPPS 蛍光像（左）と同部の等時マップ (中). 誘発された心房細動の心電図（右). (B) 心房細動の発生起源組織 (天蓋部 : roof) 亡周囲組織 (冠静脈洞 : CS) の組織化学像. RPV : 右肺静脈, LPV : 左肺静脈, LAA : 左心耳, SEP：心房中隔, CS : 冠状静脈洞, WGA : wheat germ agglutinin 染色, Masson : Masson's trichrome 染色. (文献 11 より転載)

る心房細動の発生基質を明らかにするため, 実際に心房 細動を誘発してその起源となる部位の詳細な組織形態 と組織化学の解析を行った. ラットの摘出心肺灌流組織 を用いて膜電位感受性蛍光色素 di-4-ANEPPS で心房内 の興奮伝導様式を高速 CMOS カメラ（500 コマ/秒) で取得，電気的に心房を過駆動することにより心房細 動を誘発した（図 7A）ところ, 発生した心房細動の多 くは左肺静脈と左心房後壁の天蓋部にその発生起源が 同定された (25). さらに組織学的特性を解析したとこ 万, 周辺の心房組織に比べて発生起源組織で心房筋の 密度の低下や心筋配列の乱れ, Cx43 の配列異常, 線維 成分の増多を認めた（図 7B) (25)。このように, 蛍光 イメージングによる心臟の興奮伝導異常の起源同定と 組織形態や機能分子の異常との統合的解析は, 不整脈 発生の機序を探る上で有用である.

\section{9. おわりに}

機能している心臓組織の $\mathrm{Ca}^{2+}$ 動態や膜電位変化を高 い時間空間分解能で蛍光可視化することによって, 不 整脈の発生につながる機能異常を捉えることができた. 併せて従来の組織化学的手法である組織形態や機能分 子の空間的分布をとらえ，これらの情報を統合するこ とで不整脈の発生機序の理解が一段と深まった。ここ で紹介した心臓に限らず，様々な蔵器や組織・細胞を
生きたありのままの状態で実際に視覚化することによ り, 多様な生命現象や病態の理解が媣まるものと期待 できる.

著者の利益相反：開示すべき利益相反はない.

\section{文献}

1) 河田聡 編. 新しい光学顕微鏡 第一巻 レーザー顕微鏡の 理論と実際. 学際企画; 1995.

2) Takamatsu T, et al. Cell Struct Funct. 1991;16:341-346.

3) Hama T, et al. Cell Signal. 1998;10:331-337.

4) Bers DM. Nature. 2002;415:198-205.

5) Kaneko T, et al. Circ Res. 2000;86:1093-1099.

6) Tanaka H, et al. J Mol Cell Cardiol. 2002;34:1501-1012.

7) Fujiwara K, et al. Circ Res. 2008;103:509-518.

8) Pogwizd SM, et al. Circ Res. 2001;88:1159-1167.

9) Bers DM, et al. Circ Res. 2003;93:487-490.

10) Priori SG, et al. Circulation. 2001;103:196-200.

11) Tanaka H, et al. Pathol Int. 2017;67:8-16.

12) Eisner DA, et al. Exp Physiol. 2004:90:3-12.

13) Weiss JN, et al. Circ Res. 2006;98:1244-1253.

14) Euler DE. Cardiovasc Res. 1999;42:583-590.

15) Nearing BD, et al. Science. 1991;252:437-440.

16) Jiang Y, et al. Acta Histochem Cytochem. 2014;47:59-65.

17) Xie W, et al. J Mol Cell Cardiol. 2013;64:120-123.

18) Guo A, et al. Cardiovasc Res. 2013;98:204-215.

19) Song LS, et al. Proc Natl Acad Sci U S A. 2006;103:4305-4310.

20) Louch WE, et al. Cardiovasc Res. 2015;62:63-73.

21) Severs NJ, et al. Cardiovasc Res. 2004;62:367-377.

22) Nakagami T, et al. Cardiovasc Res. 2008;79:70-79.

23) Nguyen TP, et al. J Mol Cell Cardiol. 2014;70:83-91.

24) Haïssaguerre M, et al. N Engl J Med. 1998;339:659-666.

25) Matsuyama TA, et al. Heart Rhythm. 2013;10:1342-1348. 


\title{
Fluorescence imaging of the living heart for understanding the basis of arrhythmias
}

\author{
Hideo Tanaka
}

Department of Pathology and Cell Regulation, Graduate School of Medical Science, Kyoto Prefectural University of Medicine

\begin{abstract}
Recent outstanding progress in microscopic imaging technology and the advent of fluorescent probes have enabled us to visualize high spatiotemporal dynamics of intracellular molecules in living tissues. Here I introduce our research outcomes on functional fluorescence imaging of the heart especially for understanding the pathogenesis of cardiac arrhythmias. On the in situ $\mathrm{Ca}^{2+}$ imaging of perfused rat heart by rapid-scanning confocal microscopy, we found that burst emergence of intracellular $\mathrm{Ca}^{2+}$ waves evokes arrhythmogenic triggered activity and subsequent oscillatory depolarizations via the $\mathrm{Na}^{+}-\mathrm{Ca}^{2+}$ exchanger. Besides, impairment of $\mathrm{Ca}^{2+}$ release from the sarcoplasmic reticulum leads to emergence of $\mathrm{Ca}^{2+}$ waves and spatiotemporally inhomogeneous $\mathrm{Ca}^{2+}$ dynamics on systole, resulting in beat-to-beat $\mathrm{Ca}^{2+}$ alternans. Such alternating behaviors of $\mathrm{Ca}^{2+}$ dynamics are partly due to poor development of the transverse tubules, which are identified in murine atria and failing ventricular myocytes. In addition, impairment of the gap junctional communication via connexin 43 induced by dominant negative inhibition of neonatal rat ventricular myocyte monolayers results in generation of spiral wave reentry, suggesting the pivotal role of intercellular communications in genesis of arrhythmias. Furthermore, alterations in atrial histoanatomy, e.g., density and arrangements of myocytes and distribution of $\mathrm{Cx} 43$, could provide intrinsic arrhythmogenic bases of atrial fibrillation, which was revealed by combined optical imaging of the atria and precise histoanatomical examinations. In combination, fluorescence imaging of the living organisms provides indispensable information for unveiling functions and disease states.
\end{abstract}

